\title{
DESIGN, SYNTHESIS AND ANTIMICROBIAL ACTIVITIES OF 1,4-DIHYDROPYRIDINES
}

\section{N. Venu Madhav ${ }^{1}$, Chinna Eswaraiah ${ }^{2}$ and A. Srinivas Nayak ${ }^{3^{*}}$}

${ }^{1}$ St'Peters Institute of Pharmaceutical Sciences, Warangal, Telangana, India.

${ }^{2}$ University College of Pharmaceutical Sciences, Satavahana University, Karimnagar, Telangana, India ${ }^{3}$ Anurag Pharmacy College, Kodad, Khammam, Telangana, India.

\begin{abstract}
Eight differently substituted 1,4-dihydropyridines have been synthesized by conventional and microwave irradiation methods using three components viz., ethyl acetoacetate (1) appropriate aldehyde (2) and ammonium acetate (3). The synthesized compounds have been purified and characterized by analytical and spectral data. The methods employed have been compared in terms of yields, reaction times. Microwave methods are easy simple, eco-friendly and the reactions are rapid and high yielding. The synthesized compounds have been screened for their antimicrobial activity by standard experimental procedures using ciprofloxacin as standard drug.
\end{abstract}

Keywords: Microwave irradiation (MWI), Dihydropyridines (DHPs), Calcium channel blockers.

\section{INTRODUCTION}

1,4-Dihydropyridines ${ }^{1}$ are used to treat angina and hypertension, as calcium channel blockers $^{2}$. Several of their derivatives are also reported to exhibit a variety of biological and pharmacological activities, viz., bronchodilator $^{3}$, anticancer4, antiasthmatic ${ }^{5}$ anticonvulsant ${ }^{6}$, platelet aggregation inhibitors ${ }^{7}$. Hence, this field has-ever-growing importance resulting in the development of new dihydropyridines. Keeping in view of an array of applications it has been considered worthwhile to synthesize some new biologically potent dihydropyridines by two different procedures, i.e., conventional method and microwave irradiation (MWI) methods ${ }^{8}$ with an aim to screen for microbial activities. The synthesized compounds has been purified and characterized with the help of their analytical and spectral (IR, ${ }^{1}$ HNMR \& Mass) data.

Ethylacetoacetate (1) was subjected to a modified Hantzsch reaction (cyclocondensation) with aliphatic or aromatic aldehyde (2) and ammonium acetate (3) in alcohol as solvent by conventional and MWI methods (Scheme-I).

The product obtained in each of such reactions was purified and characterized as 4-alkyl/aryl3,5-dicarboethoxy-2,6-dimethyl-1,4dihydropyridines. In MWI method, the reaction time was considerably reduced (6 min only) with increased percentage yields (70-90\%) when compared with the conventional method. Physical data of new 1,4-dihydropyridines are presented in Table-1. 
<smiles>CCOC(=O)CC(C)=O</smiles>

1

Ethyl acetoacetate<smiles>[R]C=O</smiles>

2

Aliphatic, Aromatic, or Hetero aromatic Aldehyde<smiles>CC(=O)O[18O]</smiles>

3

Ammonium Acetate<smiles>[R]C1([2H])C(C(=O)OCC)=C(C)NC(C)=C1C(=O)OCC</smiles>

1,4-Dihydropyridine

\section{EXPERIMENTAL}

Experimental procedures are given as general methods. Melting points of newly synthesizes compounds were determined in open capillaries using Toshnwal melting point apparatus. Infra-red spectra of the compounds were recorded in $\mathrm{KBr}$ pellet using Shimadzu FTIR-8700 spectrometer, ${ }^{1} \mathrm{H}$ NMR spectra on omega- $500 \mathrm{MHz}$ spectrometer using TMS as internal standard and mass spectra by the direct inlet method on VG micromass $7070 \mathrm{H}$ spectrometer operating at $70 \mathrm{ev}$.

General Procedure for the synthesis of 4Alkyl/aryl/heteroaryl-3,5-dicarboethoxy-2,6dimethyl-1,4-dihydropyridines (4a-h).

\section{Conventional Method}

A mixture of ethylacetoacetatae $(1 ; 0.05 \mathrm{M})$ and an appropriate aldehyde $(2 ; 0.025 \mathrm{M})$ were taken into a RB flask and dissolved in alcohol $(25 \mathrm{ml})$ by shaking. To this solution add ammonium acetate $(3 ; 0.025 \mathrm{M})$ and the reaction mixture was heated under reflux for 12-16 h, on a hot water bath. Progress of the reaction was monitored by TLC. After completion of the reaction alcohol was removed to a possible extent by distillation and the residue was cooled and triturated with crushed ice. The product was filtered, washed with small portion of cold water and dried and compounds were purified by recrystallization from hot alcohol.

\section{Microwave Irradiation Method}

A mixture of ethylacetoacetate $(1 ; 0.05 \mathrm{M})$ and an appropriate aldehyde $(2 ; 0.025 \mathrm{M})$ were taken into a beaker and dissolved in dimethylformamide $(10 \mathrm{ml})$. To this solution add ammonium acetate (3; $0.025 \mathrm{M})$ with stirring. A funnel was hanged in the beaker and covered with a watch glass. The reaction mixture was heated under MW irradiation at $480 \mathrm{~W}$ for appropriate time. After the reaction was completed, monitored by TLC, the reaction mixture was poured into ice-water; the obtained precipitate was filtered and crystallized from ethanol-water.

Adopting the above two procedures eight different 4-Alkyl/aryl/heteroaryl-3,5- 
dicarboethoxy-2,6-dimethyl-1,4-

dihydropyridines (4a-h) were synthesized and characterized.

Spectral characterization data of the compound (4b)

IR $\left(\mathrm{KBr}, \mathrm{Cm}^{-1}\right)$ v

3342 (-NH of DHP), 3058 (C-H, aromatic) 2980 (C-H of aliphatic), $1660\left(\mathrm{C}=\mathrm{O}\right.$, of $\left.\mathrm{CO}_{2} \mathrm{Et}\right)$, and 1594 ( $\mathrm{C}=\mathrm{C}$, aromatic).

${ }^{1} \mathrm{H}$ NMR $\left(\mathrm{CDCl}_{3}, 300 \mathrm{MHz}, \mathrm{ppm}\right) \delta$

$1.28\left(6 \mathrm{H}\right.$, of $-\mathrm{CH}_{2} \mathrm{CH}_{3}$ at $\mathrm{C}_{3} \& \mathrm{C}_{5}$ of DHP), 2.28 $\left(6 \mathrm{H}\right.$ of $-\mathrm{CH}_{3}$ at $\mathrm{C}_{2} \& \mathrm{C}_{6}$ of DHP), 4.24 (4H of $\mathrm{CH}_{2} \mathrm{CH}_{3}$ at $\mathrm{C}_{3} \& \mathrm{C}_{5}$ of DHP), $4.92(1 \mathrm{H}$ of $-\mathrm{CH}$ of DHP), $5.68\left(1 \mathrm{H}\right.$ of $-\mathrm{NH}$ at $\mathrm{C}_{4}$ of $\left.\mathrm{DHP}\right)$, and $0.96\left(3 \mathrm{H}\right.$ of $-\mathrm{CH}_{3}$ at $\mathrm{C}_{4}$ of DHP).

\section{Mass spectrum}

Recorded its heaviest ion at $\mathrm{m} / \mathrm{z} 267$, which is in agreement with the mass (mol.wt.) of its assigned structure.

Thus based on the spectral data the compound has been characterized as 4(methyl)-3,5-dicarboethoxy-2,6-dimethyl-1,4dihydropyridine $\left(4 \mathrm{~b} ; \mathrm{R}=\mathrm{CH}_{3}\right)$.

\section{ANTIMICROBIAL ACTIVITY}

The antimicrobial activities of compounds $4 a-$ h were screened by cup-plate ${ }^{[10]}$ method against Klebsiella pneumoniae, Escherichia coli, Bacillus subtilis, and Staphylococcus aureus. The structure activity relationship analysis of the compounds was compared to the standard drug ciprofloxacin at concentration of $10 \mu \mathrm{g} / \mathrm{ml}$. The bacterial zones of inhibition values $(\mathrm{mm})$ are given in Table 2 .

\section{RESULTS AND DISCUSSION}

4-Alkyl/aryl/heteroaryl-3,5-dicarboethoxy-2,6dimethyl1,4-dihydropyridines (yield 70-90\%) could be successfully synthesized by a modified Hantzsch method. Among the two different experimental methods adopted: (a) Conventional method and (b) MWI method, a significant increase in yields with a shorter reaction times have been recorded in the later (MWI) method, when compared with conventional methods which involves longer reaction times under refluxing conditions with moderate yields. All the eight compounds have been evaluated for their antibacterial activity $(100 \mu \mathrm{g} / \mathrm{ml})$.

Compounds 4a-h were screened for Klebsiella pneumoniae and compound $\mathbf{4 g}, \mathbf{4 d}$ and $\mathbf{4 h}$ were more active when compared with other compounds. Remaining compounds showed mild to moderate antibacterial activity.

Compounds 4a-h were screened for Escherichia coli and compound $\mathbf{4 g}$ and $\mathbf{4 h}$ were equipotent because the dihydropyridine contains a heterocyclic ring at 4-position. Remaining compounds showed mild to moderate antibacterial activity.

Compounds 4a-h were screened for Bacillus subtilis and compound with electron withdrawing groups (Nitro) showed more activity (4d) when compared with electron releasing group (methoxy).

Compounds 4a-h were screened for Staphylococcus aureus and compound $\mathbf{4 h}, \mathbf{4 g}$ and $\mathbf{4 d}$ was found to be more active when compared with other compounds.

Among all the compounds, dihydropyridines containing electron withdrawing groups $\left(-\mathrm{NO}_{2}\right)$ and heterocyclic (pyridyl) has been found to be greater inhibitory effect against the bacteria. Remaining all the compounds have moderate anti bacterial activity.

\section{CONCLUSION}

A new series of 1,4-dihydropyriodine derivatives $\mathbf{4 a - h}$ was synthesized and characterised. The synthesized compounds were screened for their antibacterial activity. Among the series of compounds, $\mathbf{4 d}, \mathbf{4 g}, \mathbf{4 h}$ were more inhibitory activity, but when compared with standard drug, ciprofloxacin the activity is less. These findings could be of importance for further studies in this field.

Table 1: Physical and analytical data of 4-alkyl/aryl/heteroaryl-3,5-dicarboethoxy2,6-dimethyl-1,4-dihydropyridines (4a-h)

\begin{tabular}{|c|c|c|c|c|c|c|}
\hline $\begin{array}{c}\text { Compound } \\
\text { Code }\end{array}$ & $\mathbf{R}$ & Mol.Formula & Mol.Wt & $\begin{array}{c}\text { Method-A } \\
\text { (\% yield) }\end{array}$ & $\begin{array}{c}\text { Method-B } \\
\text { (\% yield) }\end{array}$ & m.p( $\left.{ }^{\circ} \mathbf{C}\right)$ \\
\hline $4 \mathrm{a}$ & $\mathrm{H}$ & $\mathrm{C}_{13} \mathrm{H}_{19} \mathrm{NO}_{4}$ & 253 & 80 & 95 & $176-178$ \\
\hline $4 \mathrm{~b}$ & $\mathrm{CH}_{3}$ & $\mathrm{C}_{14} \mathrm{H}_{21} \mathrm{NO}_{4}$ & 267 & 78 & 86 & $120-122$ \\
\hline $4 \mathrm{c}$ & $\mathrm{C}_{6} \mathrm{H}_{5}$ & $\mathrm{C}_{19} \mathrm{H}_{23} \mathrm{~N}_{1} \mathrm{O}_{4}$ & 329 & 52 & 93 & $150-152$ \\
\hline $4 \mathrm{~d}$ & $4-\mathrm{NO}_{2} \mathrm{C}_{6} \mathrm{H}_{4}$ & $\mathrm{C}_{19} \mathrm{H}_{22} \mathrm{~N}_{2} \mathrm{O}_{6}$ & 374 & 54 & 92 & $130-132$ \\
\hline $4 \mathrm{e}$ & $4-\mathrm{OCH}_{3} \mathrm{C}_{6} \mathrm{H}_{4}$ & $\mathrm{C}_{20} \mathrm{H}_{25} \mathrm{~N}_{1} \mathrm{O}_{5}$ & 359 & 41 & 86 & $148-150$ \\
\hline $4 \mathrm{f}$ & $3,4,5-(\mathrm{OCH} 3)_{3} \mathrm{C}_{6} \mathrm{H}_{2}$ & $\mathrm{C}_{22} \mathrm{H}_{29} \mathrm{NO}_{7}$ & 419 & 76 & 79 & $140-142$ \\
\hline $4 \mathrm{~g}$ & $2-F u r y l$ & $\mathrm{C}_{17} \mathrm{H}_{21} \mathrm{NO}_{5}$ & 319 & 63 & 72 & $160-162$ \\
\hline $4 \mathrm{~h}$ & $2-\mathrm{Pyridil}$ & $\mathrm{C}_{18} \mathrm{H}_{22} \mathrm{~N}_{2} \mathrm{O}_{4}$ & 330 & 69 & 82 & $196-198$ \\
\hline
\end{tabular}


Table 2: Antimicrobial activity of 4-alkyl/aryl/heteroaryl-3,5dicarboethoxy-2,6-dimethyl-1,4-dihydropyridines

\begin{tabular}{|c|c|c|c|c|c|}
\hline \multirow{2}{*}{ SI.No } & \multirow{2}{*}{$\begin{array}{c}\text { Compound } \\
\text { Code }\end{array}$} & $\begin{array}{c}\text { Klebsiella } \\
\text { pneumoniae }\end{array}$ & $\begin{array}{c}\text { Escherichia } \\
\text { coli }\end{array}$ & $\begin{array}{c}\text { Bacillus } \\
\text { subtilis }\end{array}$ & $\begin{array}{c}\text { Staphylococcus } \\
\text { aureus }\end{array}$ \\
\cline { 3 - 6 } & $4 \mathrm{a}$ & 6 & 5 & 7 & 6 \\
\hline 1 & $4 \mathrm{~b}$ & 7 & 7 & 9 & 8 \\
\hline 3 & $4 \mathrm{c}$ & 6 & 5 & 6 & 9 \\
\hline 4 & $4 \mathrm{~d}$ & 12 & 7 & 13 & 9 \\
\hline 5 & $4 \mathrm{e}$ & 9 & 5 & 8 & 8 \\
\hline 6 & $4 \mathrm{f}$ & 8 & 9 & 10 & 12 \\
\hline 7 & $4 \mathrm{~g}$ & 10 & 12 & 7 & 13 \\
\hline 8 & $4 \mathrm{~h}$ & 14 & 12 & 10 & 20 \\
\hline 9 & Ciprofloxacin & 18 & 18 & 18 & \\
\hline
\end{tabular}

\section{REFERENCES}

1. Hantzsch. Ber. 1881;14:1637.

2. Manhold R, Jablonka B, Voigt $W$ and Schraven E. Calcium and calmoduline antagonism of elnadipine derivatives. Eur J Med Chem. 1992;(27):229-235.

3. Suresh T, Swamy SK and Reddy VM. Synthesis and bronchodilatory activity of new 4-aryl-3,5-bis(2-chlorophenyl)carbamoyl-2,6-dimethyl-1,4-

dihydropyridines \& their 1 -substituted analogues, Indian Journal of Chemistry. 2007;46(B):115-121.

4. Shah $A$, Kawase $M$ and Sakagami $H$. 3,5-dibenzoyl 1,4-dihydropyridines and multi drug reversal in tumer cells, Bioorganic and Medicinal Chemistry. 2002;10:1051.

5. Rhee MV, Jiang JL, Neli $M$ and Jacobson KA. interaction of dihydropyridines and pyridines with adenosine receptors. J Med Chem. 1996;39:2980-2989.

6. Surendra Kumar R, Idhayadhulla A, Jamal Abdul Nasser A, Kavimani S and Indumathy $S$. Synthesis and Anticonvulsant Activity of a New Series of 1,4-Dihydropyridine Derivatives. Indian J Pharm Sci. 2010;72(6):719-725

7. Sunkel CE, Priego JG and Ortega PM. J Med Chem. 1990;33:32053210.

8. Jean JacquesVanden Eynde and Annie Mayence. synthesis and aromatization of 1,4-dihydropyridines under microwave irradiation. Molecules. 2003;8(4):381-391

9. Cruickhank R, Dugurid JP, Marmion BP and Swain RH. Medicinal Microbiology. (Churchill Livingstone, London and Newyork). 1975;2:190. 